\title{
Grazing management affects nutrient intake by steers graz- ing tallgrass prairie
}

\author{
F.T. MCCOLLUM, III AND ROBERT L. GILLEN
}

Authors are professor of Animal Science and Extension Beef Cattle Specialist, Texas A\&M Research and Extension Center, Amarillo, Tex. 79109, and research scientist, Southern Plains Range Research Station, USDA-ARS, Woodward. Okla.

\begin{abstract}
Indicators of nutrient intake were compared for beef steers graxing tallgrass prairie managed with continuous grazing or 8paddock short-duration grazing. Two replicates of each grazing system were evaluated during the 2 year study. Stocking rates for the grazing systems were similar in both years. Within each treatment replicate, 3 steers fitted with ruminal and duodenal cannulae grazed for the entire grazing season (late April through late September) with larger groups of intact steers. Rest periods for the 8-paddock cells were lengthened as the season progressed and forage accumulation rate slowed. Trials occurred in early June and early August in year 1 and early July and early September in year 2. Flow of organic matter and nitrogen at the duodenum, fecal nitrogen concentration, and fecal output were used as indicators of nutritional status. Chromic oxide was used as a flow marker. Flow of organic matter, total nitrogen, and microbial nitrogen at the duodenum in addition to fecal output were lower $(P<0.04)$ with short-duration grazing and indicate that forage intake and digestible organic matter intake were depressed in steers on the short-duration grazing treatment. Forage digestible organic matter intake, estimated from microbial protein flow, was $19.3 \%$ lower $(P<0.03)$ on short-duration grazing. Fecal nitrogen concentration was higher $(P<0.03)$ for steers under continuous grazing. Diet crude protein estimuted from fecal nitrogen was $24.4 \mathrm{~g} \mathrm{~kg}^{-1}$ organic matter higher for continuous grazing. These results suggest that both diet nutrient composition and intake were depressed in steers in the shortduration grazing treatment. These observations partially explain the lower weight gains and higher end-of-season residual standing vegetation noted with short-duration grazing in concurrent grazing trials on these rangelands.
\end{abstract}

Key Words: rangeland, short-duration grazing, nutrition, forage intake

The information presented in this report is part of a broader effort to determine the effects of stocking rate and grazing method on tallgrass prairie vegetation and steer production from these rangelands. Recently, we reported that 4 complete cycles

This research was supported by project $\mathrm{H}-21 \overline{21}$ of the Oklahoma Agr. Experiment Station. Corresponding author: Ted McCollum, III, Texas A\&M Research and Extension Center, 6500 Amarillo Blvd. West, Amarillo, Tex. 79106: Tele. 806-359-5401.

Manuscript accepted 14 Jan, 1997. through an 8-paddock system optimized nutrient composition in the diets of steers grazing tallgrass prairie in the spring and summer (McCollum et al. 1994). However, forage intake was not measured in that study. Tiller defoliation studies have shown that cattle grazing tallgrass prairie discriminate among big bluestem [Andropogon gerardii Vitman], indiangrass [Sorghastrum nutans (L.) Nash] and little bluestem [Schizachyrium scoparium (Michx.) Nash] (Gillen et al. 1990; Jensen et al. 1990). Jensen et al. (1990) observed that big bluestem tillers reached a moderate level of defoliation several days earlier than tillers of either indiangrass or little bluestem. Because of selective grazing, cattle can maintain diet quality at a relatively high level but possibly at the expense of forage intake (Forbes 1987).

In 1989, we initiated production-scale research to compare vegetation dynamics and steer performance under continuous and rotational grazing management on tallgrass prairie. Over a 6-year period, steer performance was consistently lower under rotational grazing (Gillen et al. 1992; unpub. data R.L. Gillen and F.T. McCollum). In addition, more residual forage has been present in the rotationally grazed units at the end of the grazing season (Cassels et al. 1995). Based on defoliaton studies and steer performance in these same experimental pastures, Derner et al. (1994) hypothesized that the higher end-ofseason residue, as well as lower steer performance, resulted from reduced forage intake by the steers rather than increased forage production in the rotationally grazed units. The following study was undertaken to determine if forage and nutrient intake were indeed different for steers grazing tallgrass prairie managed with continuous or 8-paddock short-duration grazing.

\section{Study Area}

The study was conducted on the Oklahoma Agricultural Experiment Station Research Range approximately $21 \mathrm{~km}$ southwest of Stillwater, Okla. Climate of the area is continental with an average growing season of 204 days extending from April to October. Annual mean temperature is $15^{\circ} \mathrm{C}$ with average minimum and maximum temperatures ranging from $-4.3^{\circ} \mathrm{C}$ in January to $34^{\circ} \mathrm{C}$ in August. Precipitation in Stillwater averages $831 \mathrm{~mm}$ with $65 \%$ falling as rain between May and October (Myers 1982).

Primary range sites on the study area were shallow prairie, loamy prairie, eroded prairie, and sandy savannah. At the time of the study, the vegetation on the prairie sites was in a high seral state (Derner et al. 1994) and consisted of $28 \%$ little bluestem, 
$30 \%$ big bluestem, indiangrass, and switchgrass [Panicum virgatum L.], 25\% midgrasses, and the remainder being forbs, shortgrasses, and annual grasses (Derner et al. 1994).

\section{Methods}

Grazing treatments consisted of continuous grazing and 8-paddock short-duration grazing at common stocking rates. The treatments were replicated twice. The stocking rates for the 2 replicates were 1.17 and 1.3 ha head $^{-1}$. Within replicate, stocking rates were similar for the 2 grazing treatments. The grazing units were between 20.6 and 25.5 ha in size and were grazed with 16 to 21 head of beef steers. Grazing was initiated in late April and terminated in late September in both years of the study. Rotation schedules were based on previous research at this location (Gillen et al. 1990, McCollum et al. 1994). Four grazing cycles were completed during a 5 month spring/summer grazing season. Average rest periods were lengthened from 21 days in cycle 1 to 49 days in the final cycle. Grazing and rest periods within a cell were adjusted for paddock quality differences. A "Paddock quality" value was assigned to each paddock within an 8-paddock unit based on soil type and estimated forage production for the paddock. These values were initially assigned in 1989 when the actual grazing studies began. Each year, paddock ratings were evaluated and adjusted based on end-of-season residue levels. The pastures were not burned in either year and chemical herbicides and fertilizers were not applied in either year. Methods for any of the vegetation measurements mentioned in the text were described by Cassels et al. (1995).

Three steers fitted with cannulae in the rumen and proximal duodenum were included in each of the herds grazing the 4 experimental units ( 12 head total/year). A different set of steers was used each year. In year 1 , initial weights for the treatment replicates averaged from 384 to $388 \mathrm{~kg}$ head while in year 2 the initial weights averaged from 351 to $360 \mathrm{~kg} \mathrm{head}^{-1}$ for the replicate groups. The cannulae were surgically fitted by licensed veterinarians in the Oklahoma State University School of Veterinary Medicine. All experimental procedures had been approved by the University Animal Care Committee.

Two trials were conducted each year to quantify measurements indicative of forage intake and nutrient concentration. Each trial lasted a total of 16 days that included an 8 day marker adaptation period followed by an 8 day sample collection period. In year 1 , the trials were initiated on May 22 and August 5. In year 2, the trials were initiated on June 27 and September 16. During each trial, a slow-release chromic oxide bolus (Captec) was placed in the rumen of each cannulated steer. Chromium payout (mg $\mathrm{Cr} /$ day) was assumed to be equal to the manufacturer's specifications for each set of boluses used in the trials. We acknowledge that chromium payout ( $\mathrm{mg} \mathrm{Cr} /$ day) may not be equivalent to manufacturer's specifications. However, at the end of each trial, the boluses were retrieved from the rumen and plunger travel was measured to insure that payout (total marker medium) was consistent across steers and treatments. In all trials, plunger travel was similar across steers within a trial. Because we were interested in the relative differences among treatments, the bolus was considered adequate without validating actual daily marker payout (mg Cr/day).

Across the 8 day collection periods, treatment replicates were sampled on alternate days at 0700 and 1900 hour. At each sam- pling time, a grab sample of feces was collected along with 500 $\mathrm{ml}$ of digesta from the duodenum. Over the 8 day period, $8 \mathrm{sam}$ ples of feces and digesta were obtained from cach steer (4 morning and 4 evening samples). The samples were refrigerated until the end of each trial and were then composited across days within steer. The fecal samples were dried in a forced air oven and digesta samples were lyophilized. All samples were ground through a $2 \mathrm{~mm}$ screen and analyzed for dry matter, ash, Kjeldahl nitrogen ( $\mathrm{N}$; AOAC 1984), and chromium (Williams et al. 1962). In addition, the digesta samples were analyzed for purines (Zinn and Owens 1986).

Fecal output and digesta flow at the duodenum were estimated from chromium dilution in the feces and digesta. Microbial protein concentration in the duodenal digesta was estimated using purines as a marker (Zinn and Owens 1986) and daily microbial protein flow at the duodenum was calculated using the digesta flow estimates. Microbial protein production in the rumen is a function of the digestible organic matter intake (NRC 1985; AFRC 1993). Hence, digestible organic matter intake (DOMI) can be estimated from microbial protein production in the rumen. We estimated DOMI using the function: Microbial crude protein $\left(\right.$ g day $\left.^{-1}\right)=110.5676 *\left(\right.$ DOMI kg day $\left.{ }^{-1}\right)\left(r^{2}=0.82 ; s_{y \cdot x}=50.5\right)$, which was developed based on research conducted with steers grazing tallgrass prairie at this location (Campbell 1989; McCollum 1991) and is similar to the function used by the NRC (1985) and AFRC (1993). Total forage intake (kg organic matter day $^{-1}$ ) was estimated as the sum of fecal organic matter output (indigestible intake) and DOMI. Forage digestibility (\%) was calculated as DOML/(DOMI + fecal output). Finally, diet crude protein was estimated based on the relationship: Diet crude protein $(\%$ of organic matter $)=6.25 *((0.79 *$ Fecal $N)-0.17)\left(r^{2}=\right.$ $0.74 ; \mathrm{s}_{\mathrm{y} \cdot \mathrm{x}}=0.19 ;$ McCollum 1990) developed with steers grazing tallgrass prairie at this location. Fecal $N$ was expressed as a $\%$ of organic matter.

The experiment was analyzed using analysis of variance procedures (Lentner and Bishop 1986). Individual grazing units were treated as experimental units (16 df uncorrected). The model main effects were trial period within year, grazing system, and year, and the 2- and 3-way interactions of these terms. Trial period within year, grazing system, and the 2-way interaction of these effects were tested with an error term consisting of the interactions of replicate with these main effects. Year and all interactions of year with trial period and grazing system were tested with the residual error term.

\section{Results and Discussion}

Residual forage measured at mid-season and end-of-season in the pasture replicates is presented in Table 1 . As described by Cassels et al. (1995), more forage was present on the short-duration grazing units at the end of the grazing season. For the specific grazing units in this experiment, end-of-season residual forage was 27 to $77 \%$ higher under short-duration grazing depending on replicate and year.

No interactions ( $\mathrm{P}>0.15$ ) were observed between year and grazing system or grazing system and trial period. No 3-way interactions were significant $(P>0.15)$. In some instances, the interaction of year and trial period was significant and could be attributed to the differences between years and differences in the scheduling of trial periods between years. 
Year Effects. Fecal N ( $\mathrm{P}=0.05)$, estimated diet crude protein ( $\mathrm{P}$ $=0.05)$, and estimated diet digestible organic matter $(P=0.01)$ were higher in year 2. Organic matter flow $(P=0.002)$ and $N$ flow $(P=0.01)$ at the duodenum were also higher in year 2 . We would have expected the plane of nutrition to be somewhat lower in the second year because the respective trial periods in year 2 occurred later in the growing season than in year 1. However, as indicated by differences in the mid-season and end-of-scason forage residues (Table 1), forage continued to accumulate during the latter half of the growing season in year 2. Therefore the availability of new growth was probably higher in year 2 which allowed the steers to maintain a higher plane of nutrition even though the trials occurred at more advanced periods of the growing season.

Table 1. Mid-season and end-of-season residual forage $\left(\mathrm{kg} \mathrm{ha}^{-1}\right)$ for each grazing unit during each year of the study.

\begin{tabular}{|c|c|c|c|c|c|}
\hline \multirow[b]{2}{*}{ Replication } & \multirow[b]{2}{*}{$\begin{array}{l}\text { Grazing } \\
\text { System }\end{array}$} & \multicolumn{2}{|c|}{ Year 1} & \multicolumn{2}{|c|}{ Year 2} \\
\hline & & $\begin{array}{l}\text { Mid- } \\
\text { season }\end{array}$ & $\begin{array}{l}\text { End-of- } \\
\text { season }\end{array}$ & $\begin{array}{l}\text { Mid- } \\
\text { season }\end{array}$ & $\begin{array}{l}\text { End-of- } \\
\text { season }\end{array}$ \\
\hline 1 & $\begin{array}{l}\text { Continuous } \\
\text { Short duration }\end{array}$ & $\begin{array}{l}3,065 \\
3,935\end{array}$ & $\begin{array}{l}1,875 \\
3,325\end{array}$ & $\begin{array}{l}2,470 \\
4,135\end{array}$ & $\begin{array}{l}3,440 \\
4,980\end{array}$ \\
\hline 2 & $\begin{array}{l}\text { Continuous } \\
\text { Short duration }\end{array}$ & $\begin{array}{l}4,020 \\
4,470\end{array}$ & $\begin{array}{l}3,180 \\
4,240\end{array}$ & $\begin{array}{l}3,600 \\
3,400\end{array}$ & $\begin{array}{l}4,450 \\
5,645\end{array}$ \\
\hline
\end{tabular}

Trial Period Effects. All indices of plane of nutrition were lower $(\mathrm{P}$ $<0.05)$ in trial period 2 . This difference was expected because of the changes in forage composition and associated changes in intake and digestibility that occur as the growing season progresses.

Grazing Management Effects. Daily fecal output was $11.4 \%$ higher $(P=0.02)$ and flow of digesta into the duodenum was $12.7 \%$ greater $(P=0.04)$ in steers on the continuous grazing treatment (Table 2). These 2 measurements indicate that steers on the continuous grazing treatment were consuming more forage than steers on the short-duration grazing treatment.

Total $\mathrm{N}$ flow into the duodenum was $20.6 \%(\mathrm{P}=0.04)$ greater under continuous grazing (Table 2). The elevated flow of $\mathrm{N}$ into the small intestine can be attributed to higher daily $\mathrm{N}$ intake which is a function of more $\mathrm{N}$ in diet and (or) higher daily forage consumption. Feces from steers on the short-duration grazing

Table 2. Digesta flow at the duodenum, daily fecal output and estimated daily intake of forage and digestible organic matter by steers grazing tallgrass prairie under 2 grazing management systems.

\begin{tabular}{lrrrr}
\hline \hline & \multicolumn{3}{c}{ Grazing System } & \\
\cline { 2 - 5 } & Continuous & Short duration & SEM $^{\mathrm{a}}$ & P-valuc \\
\hline Duodenal flow(g day & (1) \\
$\quad$ Organic matter & 6,893 & 6,118 & 221 & 0.04 \\
Total nitrogen & 263 & 218 & 13 & 0.04 \\
$\quad$ Microbial nitrogen & 117 & 94 & 6 & 0.03 \\
$\quad$ Feed nitrogen & 146 & 124 & 11 & 0.18 \\
Fecal output & 5,656 & 5,078 & 140 & 0.02 \\
$\quad$ (g organic matter day $^{-1}$ ) & & & & \\
Organic matter intake & & & & \\
$\quad$ (g day $^{-1}$ ) & 12,274 & 10,416 & 433 & 0.02 \\
$\quad$ Total & 6,617 & 5.339 & 338 & 0.03 \\
$\quad$ Digestible & & &
\end{tabular}

treatment contained less $N(P=0.03$; Table 3$)$ than feces from the continuously grazed steers. Based on previous research (McCollum 1990) on tallgrass prairie, this reflects a difference in dietary crude protein of $13.6 \mathrm{~g} \mathrm{~kg}^{-1}$ organic matter (Table 3 ). These observations suggest that the steers on short-duration grazing were not only consuming less forage but the nitrogen concentration in the forage was lower than forage consumed by steers on the continuous grazing treatment.

Microbial $\mathrm{N}$ flow into the duodenum was $24.5 \%$ greater in steers grazing the continuous grazing treatment (Table 2). Because microbial crude protein (microbial $N * 6.25$ ) synthesis in the rumen is an energy driven process (NRC 1985; AFRC 1993), the increased flow of microbial $\mathrm{N}$ into the small intestine indicates that steers on the continuous grazing treatment were consuming more digestible energy than steers on short-duration grazing (Table 2). The estimated digestible organic matter content of the forage consumed by steers tended to be lower $(P=0.15)$ for the short-duration grazing treatment (Table 3 ). This observation suggests that reduced total forage intake (Table 2) had a greater impact on total DOMI than did poorer diet digestibility.

Gillen et al. (1992) reported that steers grazing these shortduration grazing units gained $17 \%$ less weight than continuously grazed steers. Results were similar in a subsequent 3 year period (unpub. data R.L. Gillen and F.T McCollum). These reductions in performance were independent of stocking rate. The inferior performance of steers grazing short-duration grazing units can be explained by the lower daily forage and nutrient intake which limited the supplies of metabolizable energy and metabolizable protein available for weight gain.

Tallgrass prairie accumulates forage at relatively rapid rates during late spring and early summer with peak standing crop

Table 3. Fecal nitrogen and estimated dietary concentrations of crude protein and digestible organic matter for steers grazing tallgrass prairie under 2 grazing management systems.

\begin{tabular}{|c|c|c|c|c|}
\hline & \multicolumn{3}{|c|}{ Grazing System } & \multirow[b]{2}{*}{ P-value } \\
\hline & Continuous & Short duration & SEM $^{a}$ & \\
\hline $\begin{array}{l}\text { Fecal nitrogen } \\
\quad\left(\mathrm{g} \mathrm{kg}^{-1} \text { organic matter }\right)\end{array}$ & 20.4 & 17.7 & 0.7 & 0.03 \\
\hline \multicolumn{5}{|l|}{$\begin{array}{l}\text { Diet composition } \\
\quad\left(\mathrm{g} \mathrm{kg}^{-1} \text { organic matter }\right)\end{array}$} \\
\hline Digestible organic matter & 516.0 & 491.6 & 10.9 & 0.15 \\
\hline Crude protein & 90.1 & 76.5 & 3.5 & 0.03 \\
\hline
\end{tabular}

SEM = Standard error of the mean, $n=8$.

occurring in July (Brummer et al. 1988). During this same period, the quality of available forage and grazed diets decreases severely (Waller et al. 1972, Campbell 1989). Accompanying the changes in standing crop and quality is an increase in the heterogeneity of plant material available to grazing livestock. Steers under continuous grazing management have the opportunity to spot graze. As the grazing season progresses, the patched utilization becomes more distinct. Although this patch grazing may not be optimal for efficient forage and landscape utilization, it does afford grazing livestock the ability to continue to select forage of relatively higher quality. Rescarch is demonstrating that cattle develop spatial memory patterns that may govern the locations, and plants within a location, that are grazed. Disruption of this behavior can reduce foraging efficiency and potentially reduce intake (Laca 1993). Short-duration grazing on tallgrass prairie during the 
growing season may be a disruptive process. An objective of many intensively managed rotation-type systems is to reduce patch grazing and more evenly distribute use across locations and plants within a paddock. Even though patches may be established during the grazing periods, the patches disappear during the subsequent rest period and thereby limit the availability of fresh regrowth in the subsequent grazing period. Also, cattle do not have the opportunity to establish spatial behavior patterns and thus must reinitiate the process of locating desirable plants each time they are moved into a fresh paddock. The combination of limited availability of regrowth as well as disruption of grazing patterns could contribute to lower forage and nutrient intake.

\section{Conclusions}

Short-duration grazing significantly reduced daily forage intake which resulted in reduced supplies of metabolizable protein and metabolizable energy to the steers on this treatment and would have limited cattle performance. These observations support the hypothesis that the greater quantities of residual forage noted in the short-duration grazing treatment pastures is at least partially the result of lower forage consumption by steers grazing these units.

Total weight gain (per head) is the primary factor governing the profitability of stocker cattle production systems. These results indicate that short-duration grazing may not be the optimal management strategy for stecr production on tallgrass prairie. However, because of the numerous factors that must be considered in developing a grazing plan for a unique ranching business, one cannot completely rule out the utility of short-duration grazing for stocker cattle production on tallgrass prairie.

\section{Literature Cited}

AFRC. 1993. Energy and Protein Requirements of Ruminants. CAB International, Wallingford, U.K.

AOAC. 1984. Official Methods of Analysis (12th ed.) Assoc. Official Analyst. Chem. Washington, D.C.

Brummer, J.E., R.L. Gillen, and F.T. McCollum. 1988. Herbage dynamics of tallgrass prairie under short duration grazing. J. Range Manage. 41:264-266.

Campbell, R.R. 1989. The influence of advancing season on diet quality, intake, and rumen fermentation of cattle grazing tallgrass prairie. Ph.D. Diss., Oklahoma State Univ., Stillwater, Okla.

Cassels, D.M., R.L. Gillen, F.T. McCollum, III, K.W. Tate, and M.E. Hodges. 1995. Effects of grazing management on standing crop dynamics in tallgrass prairie. J. Range Manage. 48:81-84.

Derner, Justin D., Robert L. Gillen, F. Ted MeCollum, and Kenneth W. Tate. 1994. Little bluestem tiller defoliation patterns under continuous and rotational grazing. J. Range Manage. 47:220-225.

Forbes, T.D.A. 1987. Quantitating forage availability. pp. 143-159. In: F.N. Owens (ed.) Feed Intake By Beef Cattle. Oklahoma Agr. Exp. Sta. MP-121. Stillwater, Okla.

Gillen, R.L., F.T. McCollum, and J.E. Brummer. 1990. Tiller defoliation patterns under short duration grazing in tallgrass prairie. J. Range Manage. 43:95-99.

Gillen, R.L., F.T. McCollum, M.E. Hodges, and K.W. Tate. 1992. Livestock response to grazing systems and slocking rate on tallgrass prairie. Oklahoma Agr. Exp. Sta. MP-135, p. 420. Stillwater, Okla.
Jensen, H., R.L. Gillen, and F.T. McCollum. 1990. Effects of herbage allowance on defoliation patterns of tallgrass prairie. J. Range Manage. 43:401-406.

Laca, Emilio A. 1993. Long-term spatial memory and grazing efficiency of cattle. Research Highlights, Range and Wildlife Management, Texas Tech. Univ. 24:20. Lubbock. Tex.

Lentner, M. and T. Bishop. 1986. Experimental Design and Analysis. Valley Book Co., Blacksburg, Virg.

McCollum, F.T. 1990. Relationships among fecal nitrogen, diet nitrogen, and daily gain of steers grazing tallgrass prairie. Oklahoma Agr. Exp. Sta. MP-129, p. 232. Stillwater, Okla.

McCollum, F.T. 1991. Diet composition, in situ disappearance, and duodenal nutrient flows in cattle grazing tallgrass prairie. J. Anim. Sci. 69 (Suppl. 1):274.

McCollum, F.T., HI, R.L. Gillen, and J.E. Brummer. 1994. Cattle diet quality under short duration grazing on tallgrass prairie. J. Range Manage. 47:489-493.

Myers, H.R. 1982. Climatological data of Stillwater, Oklahoma; 1983-1980. Oklahoma Agr. Exp. Sta. Res. Rep. P-821. Stillwater, Okla.

NRC. 1985. Ruminant Nitrogen Usage. National Research Council, U.S. Academy of Science, Washington, D.C.

Waller, G.R., R.D. Morrison, and A.B. Nelson. 1972. Chemical composition of native grasses in central Oklahoma from 1947-1962. Oklahorna Agr. Exp. Sta. Bull. B-697. Stillwater, Okla.

Williams, C.H., D.J. David, and O. Lismaa. 1962. The determination of chromic oxide in faeces samples by atomic absorption spectrometry. J. Agr. Sci. 59:381.

Zinn, R.A. and F.N. Owens. 1986. A rapid procedure for purine measurement and its use for estimating net protein synthesis. Can. J. Anim. Sci. 66:157. 